\title{
Purchasing of Immovable Property by EU Citizens in Albania. Problems and Solutions During the Integration Process Toward EU.
}

\author{
Phd Candidate Silvana Dode*.
}

\begin{abstract}
:
The right to immovable property is a fundamental right under the European Community and the "Economic Constitution" of the EU. But which are the problems that the Albanian state will face and how it should address them when the buying and selling of immovable property from foreigners will be liberalized. In this paper we will specifically focus on the EU citizen right to buy land in Albania. Based on the Stabilization and Association Agreement, signed between Albania. and the $\mathrm{EU}$, for Albania arises the obligation to provide an equal treatment to EU nationals and Albania ones, concerning the right to purchase land. Through analysis of primary and secondary legislation of EU, the decisions of European Court of Justice and the European Court of Human Rights in this field, as well as Albanian legislation, there will be exposed noteworthy problems that Albania citizens and those of EU may encounter during these transactions. By analogy we will see the problems that are currently displayed in the EU member states in this field. We shall conclude that the approval by Albania of the law, which recognizes to the foreign nationals the right to acquire unconditionally immovable property, is not enough. A series of legal reforms are necessary in other areas in order to make possible the exercise of this right in the most complete and effective way possible.
\end{abstract}

Key words: free movement of capital; ownership; immovable property; Albania integration process; ECHR and ECJ decisions; Stabilization and Association Agreement.

\section{Introduction}

Mark Twain saying, "Buy land, they're not making it anymore", is being implemented in the economy of the XXI century, where interstate transaction for the transfer of land ownership FLA, ${ }^{1}$ constitute a "hot potatoe". ${ }^{2}$

The figures speak for themselves:"from 2006 to 2010 over 70 million hectares of land were bought or leased.(Sassen,2013,page 1) The remainder,5.4 million hectares reported and 1.6 million hectares cross-referenced,is in other regions, particularly Eastern Europe.(Sassen,2013,page 30)

For Albania, the sale issue of agricultural land to foreigners is a current issue for two main reasons.

First,because of the prevalence of the phenomenon of land grabbing in Eastern Europe,where is located Albania.Secondly because of the importance that represents

${ }^{1}$ Foreign Land Acquisitions

${ }^{2}$ The most flagrant case occurred in 2009. A South Korean Company,Koreano Jugore- Daewoo Logistics Corporation,aimed to buy around 1.3 milion hectares of Madagascar Island, with is ruffly $1 / 3$ of its area. This lead to the fall of the government due to protest population. 
agricultural land for Albania,since not only $24.2 \%$ of the total area consists of agriculture land ${ }^{3}$,but agriculture sector has an important contribution to the country's GDP ${ }^{4}$.In general,because Albania is a developing country, "Land ownership has a distinct impact on wealth creation in developing countries." 5

The research issue of our work is the risk of the phenomenon of agricultural land grabbing in Albania The research question is whether Albania is really before this risk and what should be done to protect local farmers.So, what concrete measures should be taken from Albania,in order that the foreign investment, which are associated with the purchase of agricultural land not to be transformed into "iron fist in a velvet glove".

But,what is Land Grabbing?Land grabbing is a global phenomenion,mostly widespread in Africa,which has become more evident after the economic crisis of 2008(Thaler,2013; White,2012).But there are academics who accepts that the true cause of this phenomenon is the tendency for expansion of the developed countries. (Makki,Geisler,2011).

Several academics have analyzed land grabbing,considering it a theme which requires immediate treatment as theoretical as well as empirical, since many times the Western European goverments "have turned a blind eye to land grabbing"(Margulis,McKeon,Borras,2013;Wolford,2013).

Land grab means "a process in which large capitalist groups encroach into territories traditionally occupied by family farmers or/and other traditional communities to introduce large-scale monocultures plantations. "(Pedlowski,2012,page 2)

Besides this phenomenon,two other global phenomena may affect the agriculture of developing countries like Albania. First,land concentration, which means concentration of agricultural land in the hands of a few farmers,mainly foreign farmers company which has as a consequence the bankruptcy of the local farmers.In EU,3\% of the toal number of the farms controlles $50 \%$ of the agriculture lands 6 .Secondly, artificializaton, the conversion of agricultural land into ground land,due tu large investment projects of foreign companies.Among several studies in recent years, for the first time these three phenomena were strongly emphasized by Hotle Alliance, which in its 2013 publication emphasized that not only the underdeveloped countries of Africa,Asia,South America are threatened by land grabbing but also the states of Central and Eastern Europe.This study is an alarm bell for Albania,which will inevitably face these phenomena,especially after EU adherence.

\section{The right of ownership of foreigners on agricultural land in the EU.}

The right to buy agricultural land primarily is related with capital movement. Capital movement is known in Chapter 4 of the Treaty of the EU and is the possibility to pass ownership of the assets 7 . Secondly, in the EU Treaty, the right to buy land in another state from EU citizens is linked with the freedom of establishment. According to

\footnotetext{
${ }^{3}$ http://open.data.al/sq/lajme/lajm/id/703/Struktura-e-tokes-sipas-Qarqeve-ne-Shqiperi-\%282011\%29

${ }^{4} 19.6 \%$ of Albania GDP for 2013 was from agriculture sector(www.instat.gov.al)

${ }^{5}$ EU,Directorate briefing,2011,page 1

${ }^{6}$ HOTL, Alliance, ECVC, 2013, page 6

${ }^{7}$ With assets is meant not only immovable property but also shares or quotas in commercial companies.
} 
Article 44 of EU Treaty, interpreted by Case of ECJ, Reisch and Others 2002: "the right to acquire... immovable property on the territory of another Member State, which is the corollary of the freedom of establishment generates capital movements when it is exercised. ${ }^{8}$

Regarding the right to buy agricultural land ${ }^{9}$,citizens of EU states should have equal treatment with nationals locals, because according Article 52 of EU Treaty: "In the field of agriculture, the EU has sought integration through CAP 10 which contains only the main pillars of the policy; while the concrete legislative acts concerning the implementation of this policy will depend on Member States" That's why it is strongly crucial the policy followed from Albania in this matter.

On one hand, EU legislation will not interfere in domestic law, regulating the right of ownership of immovable property ${ }^{11}$. But on the other hand, according to SAA ${ }^{12}$ between Albania and EU, which has entered into force in 2009, it stipulates that the Albanian legislation will gradually improve within 7 years from the effectiveness of the SAA (up to April 1, 2016) in order to facilitate the acquisition of agricultural land by nationals of EU in Albania. The goal of SAA is to provide to foreigners a treatment no less favorable than that accorded to Albanian citizens ${ }^{13}$.

But currently in Albania, restrictions on acquisition of agricultural land by foreigners have not been eliminated yet: "In the area of capital movements and payments, restrictions on the acquisition of real estate by foreigners have not been removed."14

For this reason it is fundamentally important the "transitional periods" which mean that even after EU accession, the state keeps for some years the restriction measures that provides its legislation on the sale of land to foreigners

\section{Albanian legislations}

Albanian legislation takes a special importance with regard to the process of selling land to foreigners, as this is legislation which will regulate the form of binding sales contract in agricultural land of Albania. ${ }^{15}$

First, we note that Albania does not prohibit the sale of land to foreigners in the constitution, but only in special laws, which means that the changes in relation to the purchase of land by foreigners can be done through legal changes, and does not require constitutional amendments, as in some other countries in Eastern Europe.

${ }^{8}$ http://eur-lex.europa.eu/legal-content/EN/ALL/?uri=CELEX:61999CJ0515).

${ }^{9}$ According EU Treaty,Freedom of establishment means to take up activities as self-employed persons and to set up and manage undertakings on the territory of other EU member states.

${ }^{10}$ Common Agricultural Policy

${ }^{11}$ Article 295 of the Treaty provides that:"This Treaty shall in no way prejudice the rules in Member States governing the system of property ownership."

${ }^{12}$ Stabilization and Association Agreement

13."Article 123 "Within the scope of this Agreement, each Party undertakes to ensure to physical and juristic persons of the other Party, without discrimination comparing with its citizens, the right to protect individual and their property rights to judicial and administrative authorities of the Parties.http://www.dogana.gov.al/sites/default/files/Marreveshja e Stabilizim-Asocijimit.pdf)

${ }^{14}$ Albania Progress Report, 2013, page 20

${ }^{15}$ Law No.10428, dt.02.06.2011 "For international private right"Articles 18,46 
Regarding the rights that foreigners have in Albania,they can only buy ground land,after having managed investments in accordance with the construction permit, up to a value of not less than three times the value of the land. ${ }^{16}$.Also they can buy directly apartments.But foreigners can not buy agricultural land in Albania as well as lands that contain valuable archaeological, historical, special environmental value or with military character. ${ }^{17}$

Prohibition on the purchase of agricultural land is foreseen specifically in the Law Nr.8337 / 199818, which in Article 4 stipulates that:"The transfer of the right of ownership of agricultural land, forests, meadows and pastures is not recognized to foreign physicals and juridical persons.

With the term "transfer of the right of ownership", will be understood the earning of property, primarily through donation or purchase.

But the law does not explicitly exclude the acquisition of property through inheritance, unlike some Eastern European countries such as Bulgaria or Romania, where foreign nationals can not acquire ownership with inheritance, but must transfer ownership to a local physical or juridical person.

Secondly, it becomes important to specify that in what case a buyer of land should be considered as a "foreign"19

We find the exact definition in the Law "On foreign investments", ${ }^{20}$ which provides that " a foreign" is that physical person who is a citizen of a foreign country or is a citizen of the Republic of Albania, but with permanent abroad residence. Also "foreign" are those juridical persons and entities which are established under the law of a foreign country who directly or indirectly seeks to carry out or is carrying out an investment in the territory of the Republic of Albania in accordance with its laws.

As we see above, in Albania there are not recognized as "foreign", juridical persons established in Albania, for which the most of their capital (above 50\%) is owned by foreign citizens. ${ }^{21}$

This is a problem which must find legal change, for better control of the sale of the land market to foreigners, since many foreigners create companies with head offices in Albania and can buy freely agricultural land.

In this aspect Albania resembles with Bulgaria and Romania,where this legal facilitiy increase potential opportunity for foreign companies to buy agriculture land in these countries. $^{22}$

${ }^{16}$ The law "On the purchase of the land", Nr.7980, dt.27.07.1995, Article 5. Till the investment is carried, he uses the land under

a lease contract.

${ }^{17}$ Law nr.7980, dt.27.07.1995 "For the purchase of land"

${ }^{18} \mathrm{Law} \mathrm{Nr} .8337$, dt.30.04.1998 "On transferring the ownership of agricultural land, forests, meadows and pastures"

${ }^{19}$ According to the Law "On Foreigners", No. 108/2013 stipulates that: "Foreigner is any person, with or without citizenship, who, under the law, is not an Albanian citizen."

${ }^{20}$ Law "For foreign investments", No.7764/1993

21.For example, unlike Poland where a company is considered "foreign" or if a foreign (Physical or juridical) control over $50 \%$ of the votes of shareholders.

22 Swinnen et 2010 , page 3 
This situation is quite different from Poland, which requires a prior permission from the state authorities if a foreigner intends to purchase shares in a Polish commercial company, based in Poland, which owns immovable property and if, as a result of this purchase, the foreigner will win control of this company

So in general the current regime of selling land to foreigners is strict in some ways but quite liberal in some other. Limited because agricultural land can not be subject to sale to foreign citizens (EU or third countries).Liberal because any foreigner can create a commercial company in Albania and thus can buy agricultural land in order to become owner.

\section{The Effects of the agricultural land sailing to foreigners.}

To summarize what restrictive measures can be applied to the purchase of farm land to foreigners, it is worth analyzing which are among the main benefits and risks of FLA.

First, many authors recognize the unavoidable importance of the FLA (Liu,2012;Swinnen,Vranken,2009; Jarocki,2013;Dadak,2004;Mihaljek,2005) as they stimulate the domestic economy ${ }^{23}$,increase the quantity and quality of agricultural products, bring new capital and benefits from the know-how of the investor, but alongside with it, it also strengthens ties with EU countries thereby, increasing productivity in the Member States ${ }^{24}$.Furthermore, by some researchers, liberalization of selling agricultural land to foreigners leads to increasing demand for land. An increase in the land demand leads to increased land prices, thus increasing the value of the assets that the local farmers have(Dadak,2004).

But increasing the number of land deals with foreigners in a country, is not always in the right proportion and leads to increased economic development of this state (Liu,2012).A typical case is Africa, where countries that have large sales of land to foreigners are countries at the highest positions in the global index of hunger.(Makki,Geisler,2011).

For many authors, limiting purchase of property by foreigners is of vital importance. By doing so, they preserve national security, because the purchases have substantially a neocolonial nature (Xiaojing,2011;Pedlowski,2012;Djana,2012).The focus of all researchers, nonprofit organizations and government agencies on the process of selling land to foreigners, should also be better provided.(Ianni,2012;France ministry FA,2010).

Even in many European countries, which are not part of the EU, as in Turkey (Cetinkaya,et,2013) or in Switzerland (Gautier et,1998), there is a hot debate whether to consider the sale of land to foreigners as the sale of national property.

Among the negative consequences that the purchase of land by foreigners can bring, we can mention the expropriation of local farmers' land by the state in view of foreign investment. This expropriation has had negative consequences in many developing countries (Makki,Geisler,2011;WOLFORD,2013).

${ }^{23}$ Facilitating the acquisition of agricultural land will influence the development of agriculture. Because as $19 \%$ of the GDP of Albania comes from agriculture, this will impact the improving of the economy in general.

${ }^{24}$ CEC, Report from the commission of the European communities, 2008 
Secondly, it brings the violation of healthy sustainable ecosystems, a violation that constitutes an "eco-crime" (White,2012). ${ }^{25}$

Thirdly, in violation of the national sovereignty of Albania, because there is a risk in massive purchase of agricultural land by foreigners, due to the differences that exist between land prices in Albania and those in the EU countries

Fourthly, the bankruptcy of local farmers and products from EU countries ${ }^{26}$, may risk to pervade the domestic market, as happened in many countries that joined the EU after 2002. ${ }^{27}$

Fifth, the above factor could curb domestic small farmers or young people to enter the agricultural business, as it may be required a great amount of financial cost to enter upon this business.

But despite the negative effects, the global organizations (EU,World Bank) have traditionally supported the increase of investments in developing countries. ${ }^{28}$

\section{Is Albania at risk of land grabbing.}

It is the developing countries like Albania where there is a great risk from the FLA."In Countries where governance is weak and local land rights are not clearly speltout, FLA raises a number of important risks for the local population. ${ }^{29}$ Furthermore, there where land governance sector is weak, there are happening the greater land sales transactions."(Wolford,2013;Von Braun,Meinzen-Dick,2009).

Albania is at great risk of land grabbing for some reasons, such as: the major difference between the price of land in Albania and the EU, the difference between the average income in Albania and the EU, ${ }^{30}$ the low value of labor, a geographical position at the crossroads of trading routes between Eastern and Western Europe, the appropriate climate for the development of agriculture.

In Albania, a large part of the population has emigrated, leaving behind more bare land, and an aging population mainly in rural areas, which strongly favor land grabbing. ${ }^{31}$

Also, the large number of co-owners of agricultural land, promotes FLA. The farm lands in Albania, were given back to the villagers in 1991,on the basis of the family members number of August 1991.But the more co-owners the land has, the more the opportunity arises to be purchased by a foreign corporation or to be abandoned (Swinnen, Vranken,2009).

\section{Albania can be faced with the land grabbing of agricultural land, in these two specific situations:}

25 A typical case happended in Italy where due to a project of a firm for energy production in Sardinia, hundreds of hectares of land were expropriated

${ }^{26}$ Mainly products of firms which benefit from EU subsidies

${ }^{27}$ HOTL Alliance, ECVC, 2013

${ }^{28}$ EU Directorate ad-hoc, briefing, 2011

${ }^{29}$ Asongu,Nguena,2014, page 8.

${ }^{30}$ In Albania, the average income in 2009 was $\$ 4,070$ per capita. (USAID, 2011, Albania report, page 1.)

31 The large number of migrants has influenced the income that they bring in Albania, where about 30-40\% of the GDP of Albania in 2009 consisted of remittances. (USAID, Albania report, 2011) 
Firstly, Albania has a large area of agricultural state land, which can be sold to foreigners. ${ }^{32}$ This is the land which is vulnerable to FLA. Secondly, agricultural land owned by local citizens, can be expropriated for public interest. Public interest, on the other hand, means conducting a foreign investment.

\subsection{Agricultural land problems in Albania can foster Land Grabbing.} Albania must resolve current uncertainties about property rights over real estate." 33 Some of the problems related to land market in Albania are:

a. Incomplete privatization. This is one of the main reasons EU agrees to establish the transitional period:"to ease the process of restitution and privatization of agricultural land to farmers." 34

b. Unknown and undefined or unclear ownership. The online registry of land for the entire country is still missing in Albania. According to it, the exact type of soil will be specified. Besides that, an integration of the online land data with all state institutions should be done in Albania . 35

c. The process of restitution is still in progress. From 1991 judicial processes between land users and former owners continue. ${ }^{36^{\prime \prime}}$ The estimated 41,000 claims to restitution and compensation remain largely unresolved and undermine tenure security and the development of functioning formal land markets."(Usaid,“Albania Report”,2011,page1)

d. Underutilized land and the lack of infrastructure on farm land.

e. Outstanding issues regarding land ownership continue to remain quite disturbing."Delays in application of and non-compliance with judgments of the European Court of Human Rights, with particular regard to property rights and the right to a fair trial, remained a concern." 37

According to the 2013 progress report, "Albania needs to provide protection for property rights and strengthen the rule of law." 38 The integration process of Albania is going more quickly, while legal reforms are proceeding at slow pace. The precipitation of these reforms is decisive for the future of Albania. If there will continue to be applied these legal practices in Albania, without carrying out essential reforms, it is likely that the negative effects of the acquisition of land by foreigners will prevail over the positive ones.(Eu-Directorate-ad-hoc Briefing,2011)

The fact that we can become EU members means only that we have reformed the laws in accordance with the acquis communautaire,but does not necessarily imply that the real property market is reformed. According to the European Commission "The EU

32 At least until 2014 about 134 thousand hectares of farmland in Albania are owned by the state. (Decision of Council of Ministres, Nr.405, dt.27.06.2012, "Cross-cutting strategy, the reform in the area of property rights," page 18)

${ }^{33}$ DCM Nr.438, dt.2.07.2014 "On the approval of the national plan for European Integration 2014-2020", page 124

${ }^{34}$ Raugalaite, 2012 , page 41

35 " 339 of the 470 areas of land registration plates, where there is not yet completed the initial registration, are agricultural land" (European Commission Progress Report for Albania, 2014, page 18)

${ }^{36}$ Whom the land was expropriated according to laws, acts, criminal court decisions or taken in any other unjust manner by the state from 11.29.1944.

${ }^{37}$ European Commission- Albania progress report-2013, page 42.

38 European Commission-Albania Progress report,2013- page 17 
does not have an absolute standard for determining whether a country has a functioning market economy.The EU's monitoring and evaluation of the real estate markets of applicant countries have not been consistent." 39

\subsection{The attitude of Albanian population and government on land grabbing.}

According to the neofunctionalist theory (theory that explains the creation of the $\mathrm{EU})$,not only government bodies but also non-governmental entities, through their ability to express opinions freely,are transformed into active subjects during the process of integration.This dual negotiation process will lead to a win-win solution,ie mutual benefits for both sides(Ianni, 2012) and are favored down-top suggestions by farmers to governments, in order for these transactions not to be just a top-down phenomenon,induced by global market or foreign investors(White,2012;Wolford,2013.)

It is known that there is a lack of transparency in connection with the sale of farm land to foreigners. This lack of transparency leads to restriction of the inclusion of the civil society during the negotiation process as well as during the execution of the sale agreement.In developing countries like Albania,"it has been noted that investors and host governments have every incentive to shield the land deals they conclude from public scrutiny."(Fortin,Richardson,2013).

\section{Why is it justified the limitations of the sale of agricultural land to foreigners}

The right of property is the highest form of the freedom of economic activity and this activity must be protected by the state. ${ }^{40}$

Researchers are divided into two main groups.According to a part of them,the application of transitional period and the retention of limits would affect very negatively the development of the sale market of agricultural land(Jarocki,2013;Raugalaite,2012;Dadak,2004).For example in the case of Poland it was decided to be set a period of maximum 12 years.Regarding this fact many authors expressed the idea that "the Polish economy suffers as a result of this restriction." 41

But recent studies have shown that it isn't the limitations of land acquisition by foreigners those that impede the development of the land market but the own problems of this market that existed before the accession of these countries to the EU (Swinnen,Vranken,2009).

\section{The concrete measures that can be taken by Albania in connection with the sale of agricultural land to foreigners}

The legal basis for the recognition of these limitations is provided by Article 61 of the SAA for

Albania:

"The provisions set out in Article 61 shall not be construed to prevent proportionate and non-discriminatory restrictions on the purchase of real estate based on general interest." So there will only be allowed those restrictions that are proportionate and non-

\footnotetext{
${ }^{39}$ FAO,'Land tenure Policy series",Rome,2006,Page 7(www.fao.org/3/a-a0464e.pdf)

${ }^{40}$ Decision of the Constitutional Court No.28, dt.27.05.2010

${ }^{41}$ Dadak, 2004, page 1
} 
discriminatory in the purchase of real property by foreigners.

First,regarding the restrictions applied to non-EU citizens, first, if we refer to the countries that have been members of the EU before 2002, we think that can be drawn some conclusions:a)it must be exercised control not only at the moment when sales transaction of agricultural land to foreigners takes place but also later.b)Albanian legislation should provide that in the case when an Albanian company,which owns agricultural land,passes more than $50 \%$ of its capital to foreigners, there must be taken a preliminary approval. ${ }^{42}$ So it must be kept in mind the case of Switzerland,where the permission to buy farm land is required not only for companies that are not established and that have not the headquarters in Switzerland,but for the Swiss company controlled by the foreigners,as well.Or taking into consideration the case of Ireland,where there must be received a Land Commission permission to buy agricultural land.

Setting the Transitional Period is mainly driven by the "Historical Roots",as a mean by which is aimed curbing land acquisition by foreigners, which is perceived by locals as an invasion of neighboring countries. ${ }^{43}$ Unquestionably there will be placed transitional periods,taking into account the development of agricultural land market in Albania.These are preclusion provisions in the international cooperation agreement signed between Albania and EU.During the transitional period,there can be maintained in effect the current legal measures and placing a derogation on freedom of movement of capital.This period must be exploited to the maximum for the development of the agricultural sector,because the derogation period is a transitional one,which will inevitably go towards the end (CEC,2008)

In fact SAA for Albania does not provide the establishment of a transitional period but it will only be set thanks to the negotiating skills of the Albanian state.

Setting the transitional period is supported by the liberal-intergovernmentalist theory according to which the policies of international organizations must not be a priority over the state policies that have created these organisations.In international relations,according to this theory,the main driving forces are the interests of national authorities, which aim at achieving results in their interest.So transitonal periods are one of the consequences of European integration and "bargaining processes." 44

Among the first authors to suggest setting them are Prosterman, Rolfes, since 1999. These periods according to them will avoid the negative effects of an immediate admission of the purchase of real estate by foreigners.

EU initially thought that transitional periods were contrary to the spirit of the EU and were measures only for the interest of the member states. With the passing of time EU began to have a positive attitude towards establishing the transitional period,emphasizing their necessity for the countries which just joined EU"Shorter than set transitional periods could impinge further development of the NMS. ${ }^{45 "}$ (EC,2008,page 3)

${ }^{42}$ For example in Ireland, the company must notify the state bodies, for passing the controls of it's assets to the foreigners.

${ }^{43} \mathrm{As}$ did Poland or the Czech Republic which asked the restriction of the purchase of agricultural land respectively by the German and Austrian citizens. (Wood, 2004)

${ }^{44}$ Raugalaite, 2012 , page 30

${ }^{45} \mathrm{New}$ member States 
So it is mandatory not only to establish a transitional period but it should have a sufficient duration in order to protect the local farmer.Given the fact that Albania in general is very slow in undertaking domestic reforms, we suggest that this period should last from 10 to 14 years, enabling during this period a more effective protection of farmers against expropriation of agricultural land or informal purchases by foreigners.

7.1. During the application of the transitional period,Albania could apply some mitigation measures:

Firstly,it could be gradually increased the maximum amount of agricultural land that foreigners could buy,without overpassing a certain maximum.

Secondly,there could be set less complicated procedures to strangers if they want to buy the land on which is set up the factory where they are currently developing the agricultural activity.(Swinnen,Vranken,2009).

Thirdly,self-employed farmers, nationals of a member state of the EU,who will exercise agricultural activity,shall not be subject to restrictions during the transitional period, if they aim to have a residence in Albania, and before land acquisition they had rented the land and have lived in Albania for several years.

7.2. After the transitional period has passed,there should be recognized facilities in the purchase of land by foreigners (non EU nationals) in the event that a property is purchased for the purpose of placing a business or the development of an activity and for the foreign nationals who have residences in Albania or have Albanian nationality.

But there can be placed binding measures that will continue to apply even after the transitional period has ended: a)there shouldn not be recognized the right to export agriculture products, if Albania needs these products produced by the foreign investment.b)there may be compiled concrete plans for the development of agriculture,forcing the owner to plant a crop in the ground,in accordance with the agricultural development plan (Asongu,Nguena,2014). There shouldn't change the destination of agricultural land purchased,even after the transitional period has expired. c)For foreign nationals who are not EU citizen,there can be predicted the receipt of an approval from a state institution before the transaction takes place (as in Germany,France,Sweden).

d)For any owner,regardless of his nationality, there can be applied restrictions on the maximum amount of agricultural land that they may hold. ${ }^{46}$ Or there may not be allowed the sale and division of an area of land under a minimum surface. ${ }^{47 \text { " In }}$ Albania,the law currently prohibits the division of agricultural land smaller than the " cultivation minimum unit". ${ }^{48}$ But the problem in Albania is that the law has not

46 In Hungary, the maximum amount is 300 hectares, for the physical persons, domestic and foreigners as well.

${ }^{47}$ For example in Turkey the agricultural plot can't be under 0.1 ha and in Bulgaria it can't be under 0.3 ha.

${ }^{48}$ With the "minimum unit of cultivation" is meant the agricultural land, which is necessary for maintaining an agricultural economy, according to the natural conditions of the region or area concerned. "Civil Code of the Republic of Albania, Article 228 
determined how big this area will be,which is a gap that must be filled before EU membership.

e) Some scholars accept the implementation of the "Performance Requirements" (Asongu,Nguena,2014), which means forcing foreign investors to contribute to the local economy through the purchase of inputs from domestic producers or employment and training of the local labor force.

In order to determine the specific types of restrictions that are to be applied,there must be conducted in advance by the Albanian state detailed studies of the farm land market,of the Albanian economy and the world economy trends.There is not an exhaustive list of the types of restrictions,because their types will be affected by the policies that the Albanian state shall follow,since "there is no direct correlation between the nature and extent of restrictions on foreign ownership of land and acountry's economic strength;stage of development;political system and constitutional arrangements;size;or bistory of colonisation or foreign domination.Legal restrictions on ownership and use of land by foreigners are designed to achieve a variety of policy objectives unique to the circumstances of each state." 49

What is worth mentioning is that whatever the types of restrictions that are placed,the experience of analogue countries such as Albania has shown that through "informal arrangements" and transactions through local intermediaries, the foreigners can effectively buy agricultural land,although it is prohibited. This carried through local nationals or trading companies, or by buying shares in local companies that own agricultural land(Swinnen,Vranken,2009;Report CEC,2008;Hodgson et 1999,Raugalaite,1999; Tegova,2010; Hotl ECVC Alliance,2013).50 The above problem is particularly acute for Albania, where there is effectively an informal market of lease and sale of land (Usaid,"Albania Report",2011).

\subsection{How should be the restrictions on the sale of agricultural land to foreigners according to the practice of the European Court of Justice (ECJ).}

In her practice,which shall be analyzed briefly below,the ECJ stated that these restrictions are not enough to aim to protect the public interest (for example the environment) but should absolutely: a)be applied in a non-discriminatory manner;b)to meet the test of proportionality ${ }^{51}$; c) must be reasoned.

ECJ generally has not supported the application of restriction measures. It has reached in its practice to the conclusion that:"Restrictions on cross-border land acquisitions generally amount to hindrances of free movement of capital under the Mastricht Treaty." 52

${ }^{49}$ Hodgson et 1999, page 49

50 A typical case of an informal arrangement is an informal verbal agreement between a foreign national and an albanian. According to it, the Albanian citizen undertakes the conclusion of a contract for purchasing agricultural land.But the real beneficiary will be the foreigner, to whom will pass the consequences the sale contract thorugh a second contract.Iin this case we are before an "absolute simulation".

Also there is the possibility that a foreigner can buy shares / quotas in an Albanian commercial company which is the owner of agricultural land.

${ }^{51}$ The case of the ECJ, Konle vs. Austria

${ }^{52}$ Case of ECJ, Konle vs Austria 
First, the ECJ states that ${ }^{53}$ it shall be considered acceptable by the EU Treaty principles, the domestic law which requires that the agricultural land shall be sold only to the person who will exploit and plant it.This provision,which aims the avoidance of speculative purchases, we think that may be foreseen by the Albanian legislation as well,after the expiration of the transitional period.It should apply to the foreign nationals as well as to the locals.

Secondly,the compulsion of the domestic law,that the purchaser of the agricultural land must shift his residence to the agricultural land that he has purchased,and stay in this residence for eight consequtive years, was considered by the ECJ in contradiction with the principles of free movement of capital. ${ }^{54}$ So these types of restrictions can't be applied by Albania.

Thirdly,the ECJ ${ }^{55}$ has considered as a violation of EU Treaty and an infringement of the principle of proportionality,the legal obligation to seek a preliminary approval by the Austrian state authorities, in the case when these authorities considered that land purchases by foreigners may lead to a foreign domination in the relevant municipality.

Fourthly, in the case Fearon \& Company Limited vs Irish state ${ }^{56}$, is provided that the criterion for forcing the foreign citizen,who participates in the creation of a commercial company which owns agricultural land,to come to live in the state where the agriculture property is located,is an illegal requirement.It can become legitimate only if it is nondiscriminatory,which means that it should be applied to the nationals of the country,where the property is located,as well.

So the ECJ,with its interpretation of the EU treaties,is the basis where the Albanian legislator will rely on setting the types of legal restrictions regarding the purchase of agricultural land

by

foreigners.

\section{Conclusions}

Foreign land acquisitions are being considered more and more as the cause of "disassembling of national territory",and as a factor that has led to the emergence of a global geopolitics, where the national sovereignty is now the subject of non-national authority systems(international organizations)and of controls by foreign subjects on greater surfaces of the state land.(Sassen,2013)

This trend is shown even by the initiatives undertaken within the EU57, which intend to facilitate the purchase of immovable property between the EU countries and to enable

${ }^{53} \mathrm{C}-370 / 05$ http://eur-lex.europa.eu/legal-content/EN/ALL/?uri=CELEX:62005CJ0370),

54 "Although the Danish legislation on agriculture does not discriminate between Danish nationals and nationals of the other Member States of the European Union or the European Economic Area the fact nevertheless remains that the residence requirement which it imposes and which may be waived only with the authorisation of the minister responsible for agriculture restricts the free movement of capital." http://curia.europa.eu/juris/document/document.jsf?docid $=65453 \&$ doclang $=$ en

55 Sramek vs Austria, Nr.8790/79, dt.22.10.1984,

56 -http://eur-lex.europa.eu/legal-content/EN/ALL/?uri=CELEX:61983CJ0182

${ }^{57}$ EULIS (European Land Information System), linking the system of registration of immovable property between the EU countries and the establishment of ELRA (European Land Registry Association) 
each EU citizen to fulfill,at the notary of his state,all the procedures regarding the purchase of an immovable property.

It can be concluded that the ban on acquisitions by foreigners can't be completely avoided despite the restrictions ${ }^{58}$, but there is a need for effective controls on these contracts.Even though in the Albanian legal system,"uncertainties over property ownership,delays in court procedures and weaknesses in the rule of law continue to be detrimental to the business environment." 59 It is true that the freedom of economic activity,which means among other things the freedom to invest and the free movement of capital,(domestic and foreign), is a negative freedom.But this freedom means also that the state shall guarantee "the principle of the social state and the common good" as well,aiming at protecting the market from distortions of the freedom of economic activity. ${ }^{60}$

But it should be noted that without an interstate political cooperation,undertaken between European countries, to fight land grabbing and land concentration,it will be difficult for Albania to fight alone this phenomenon.In an economy which becomes more global each day,it can't be contemplated the elimination of the FLA,despite the negative impact they may have,but efforts should be made by the Albanian government,in order for them to be as much sustainable for the environment and the local society as possible.

The conclusion of the paper is that in the long run Albania will benefit from purchases of land by foreigners, but there is a need for state policies and proportionate restrictions and for a gradual approach towards the opening of the sales market of agricultural land.

\section{Recommendations}

a.In Albania there are missing the research to determine whether the facilitation of the sale of land to foreigners, done right away,will be an accelerator or inhibitor factor for the

economy.

These studies should be carried not only in a resumptive way,regarding the EU integration process but there should be performed "impact investigations" before any sale transaction that will be carried out with a foreign company. This should be done in order to enable farmers who may be affected by the sale, to be informed and to give a "free and prior consent". 61

b. There should be involved all the stakeholders in the process of selling the farm land.It must be obtained a predominance of the local democracy,and must be increased

${ }^{58}$ Even in Poland and Slovakia, about $1 \%$ of agricultural land is owned by foreigners, although Poland, unlike Slovakia has introduced strict measures regarding the transfer of ownership to foreigners

59 Albania Progress Raport, 2013, page 16

${ }^{60}$ Decision of the Constitutional Court of Albania, No. 14, dated. 21.03.2014, Official Journal, No. 50 , dt.11.04.2014.

61 Asongu,Nguena 2014 ; Fortin, Richardson 2013 
the participation of the local communities in decision-making regarding land management. ${ }^{62}$

Also,negotiations with foreigners must be as transparent as possible,enabling FPI consent. ${ }^{63}$

c.It must be improved the legal and administrative basis connected with real property transactions.There should be set up a more efficient registration system and must be completed the process of reviewing the titles of ownership on agricultural land,which will enable the transition to the land market of more agricultural land,which currently are outside the market.

d.There must be carried out a continuous monitoring of transactions related to the sale of land to foreigners,both before and after signing the contract.It must be done a multidisciplinary study(legal,economic,environmental) on the amount of agricultural land available for the future and how it will be managed. ${ }^{64}$

e.If there are imposed restrictive measures on the purchase of agricultural land by foreigners, not only must be performed studies before setting these measures, but there also should be done studies and monitoring after the application of these measures, in order to see how effective these measures have been.

f.Land deals should be "politically acceptable".It must be prioritized the ownership of agricultural land by the people who work it effectively and not by those who buy it for different purposes rather than planting g.If foreigners buy agricultural land,it should be used only for agricultural products, and it should be aimed to eliminate as much as possible the diverting of destination of agricultural land.Agricultural products derived from these investments should be intended to be sold initially in Albania,if there is a need for them,and then out of the local market.

\section{References:}

Matias E. Margulis,McKeon.N\& Saturnino M. Borras Jr. Globalizations , 2013,“Land Grabbing and Global Governance.Critical Perspectives." Special Issue: Land Grabbing and Global Governance, Volume 10, Issue 1, 2013 ,DOI:10.1080/14747731.2013.764151

Wood.S, 2004, "A Common European Space? National Identity, Foreign Land Ownership and EU Enlargement: The Polish and Czech Cases", Geopolitics ,Volume 9, Issue 3, pages 588-607.

Gautier.H,Nussbaumer.M, 1998, "Easing of swiss Rule on Acquisition of real Estate by foreigners.". Journal" International legal practitioner"

Ianni.E, 2012,"Land Acquisitions and Rural Poverty: Unveiling Ambiguities in the District of Caia (Mozambique)", Journal Environment and Natural Resources Research; Vol. 2, No. 3; 2012 ISSN 1927-0488 E-ISSN 1927-0496.

62 Which in Albania is really problematic, since few local referenda have been held after the establishment of the democratic state in 1991.

${ }^{63}$ free, prior and informed consent.

${ }^{64}$ We can mention here the case of Albanian hidropower buildings. In the years 2000-2015 there were carried out major expropriations in favor of foreign firms (and local as well) in order to construct hydropower plants.But only recently, in 2015, it was found that these hydropower plants have caused irreparable damage to the environment, due to the lack of studies, or even though studies were carried out, they have not been conducted with seriousness. 
Thale.,K, 2013," Large-Scale Land Acquisitions andSocial Conflict in Africa", Conference paper for discussion at:Food Sovereignty: A Critical Dialogue,International Conference, September 14-15, 2013

Geisler.M,2011, "Dispossession: Land Grabbing as New Enclosures in Contemporary Ethiopia By Fouad,", Paper presented at the International Conference on Global Land Grabbing, 6-8 April 2011.

White.R, 2012, "Land Theft as Rural Eco-Crime", International Journal of Rural Criminology, Volume, 1, Issue 2 (November), 2012.

ASONGU.A;NGUENA.L, 2014, "Equitable and Sustainable Development of Foreign Land Acquisitions: what have we learnt on policy syndromes and implications",African Governance and development Institute,A G D I Working Paper WP/14/001 ,January 2014.

Fortin.E,Richardson.B, 2013, "Certification schemes and the governance of land: enforcing standards or enabling scrutiny?”, Journal Globalizations, Vol.10 (No.1). pp. 141-159. ISSN 1474-7731, Official URL:http://dx.doi.org/10.1080/14747731.2013.760910

Wolford, Wendy, et al. 2013, "Governing global land deals: the role of the state in the rush for land." Journal Development and Change 44.2 (2013): 189-210. Official URL: http://onlinelibrary.wiley.com/doi/10.1111/dech.12017/full

Li Liu, 2012, "Land acquisition in Africa for agricultural purposes. The case of sugar cane plantation and sugar mill in Ethiopia".

Pedlowski.M, 2012, “ MEGA-PROJECTS AND STATE-DRIVEN LAND GRABBING IN BRAZIL: VIOLENCE AND DISPOSSESION IN THE NAME OF ECONOMIC DEVELOPMENT”, International Conference on Global Land Grabbing II,October 17-19, 2012

Djane.S,2012, "Making Land Acquisitions Responsible through Soft Law.The Limitations and Potentials of the Responsible Agricultural Investment Initiative "

http://lup.lub.lu.se/luur/download?func=downloadFile\&recordOId=2544532\&fileOId $\equiv 2702106,2012$

CEPS, European Community,Centre for European Policy Studies, 2009, “ LAND \&EU ACCESSION REVIEW OF THE TRANSITIONAL RESTRICTIONS BY NEW MEMBER STATES ON THE ACQUISITION OF AGRICULTURAL REAL ESTATE.

France, Ministry of Foreign and European affairs, 2010, "Large-Scale LandAcquisition and ResponsibleAgricultural Investment.For an approach respecting Human Rights, Food Securityand Sustainable Development." June 2010

United Nations Interagency Framework Team for Preventive Action," Toolkit and guidance for preventing and managing land and natural resources conflict." 2012

UNDIRECTORATE-2011, GENERAL FOR EXTERNAL POLICIES OF THE UNION, , POLICY DEPARTMENT AD-HOC BRIEFING, “AN ASSESSMENT OF THE EFFECTS OF LAND OWNERSHIP AND LAND GRAB ON DEVELOPMENT, WITH A PARTICULAR FOCUS ON SMALL HOLDINGS AND RURAL AREAS."

Hodgson.S, Cullinan.C,Campbell.K, 1999, "Land OWNERSHIP AND FOREIGNERS: A COMPARATIVE ANALYSIS OF REGULATORY APPROACHES TO THE ACQUISITIONAND USE OF LAND BY FOREIGNERS”, EnAct International, FAO LEGAL PAPERS, ONLINE \#6.

Jarocki.L, 2013 "International Land Acquisition in the Polish Legal System and Its Impact on Economic Development",www.lawanddevelopment.net/img/2013papers/LukaszJarocki.pdf

Raugalaite.Jm 2012,“The Acquisition of Agricultural Land in Lithuania by Foreigners.Case study of Lithuania." Aalborg Universitet.

COMMISSION STAFF WORKING DOCUMENT ,ALBANIA,2013 PROGRESS REPORT, Brussels, 16.10.2013

Swinnen.J,Vranken.L, 2010, "Review of the transitional restrictionsmaintained by Bulgaria and Romania withregard to the acquisition of agricultural realEstate."Final Report, Centre for European Policy Studies (CEPS)

REPORT FROM THE COMMISSION TO THE COUNCIL,2010, "Review of the transitional measures regarding the acquisition of agricultural real estate foreseen in the Accession Treaty 2005", EUROPEAN COMMISSION, Brussels. 
Akkermans.B,2014, “ EUROPEAN UNION CONSTITUTIONAL PROPERTY LAW .”,MAASTRICHT EUROPEAN PRIVATE LAW INSTITUTE WORKING PAPER No. 2014/14 , www.ssrn.com

Dadak.C,2004, "THE CASE FOR FOREIGN OWNERSHIP OF

FARMLAND IN POLAND”, Cato Journal, Vol. 24, No. 3.

Gerber.L,Giovarelli.R, 2005,"Land reform and land markets in Eastern Europe",http://www.fao.org/docrep/008/y7218t/y7218t0c.htm

Gilbert.J,2013, " Land Rights as Human Rights: The Case for a Specific Right to Land",http://www.surjournal.org/eng/conteudos/getArtigo18.php?artigo=18,ar tigo $07 . \mathrm{htm}$

Mihaljek.D,2005, “FREE MOVEMENT OF CAPITAL, THE

REAL ESTATE MARKET AND TOURISM:A BLESSING OR ACURSE FOR CROATIA ON ITS WAY TO THE EUROPEAN UNION?,http://www.ijf.hr/eng/EU3/mihaljek.pdf

Prosterman.R,Rolfes.L, 1999, “AGRICULTURAL LAND MARKETS IN LITHUANIA, POLAND,AND ROMANIA: IMPLICATIONS FOR ACCESSION TO THE EUROPEAN UNION.”, RDI Reports on Foreign Aid and Development \#99.

Sassen.S,2013, "Land Grabs Today: Feeding the Disassembling of NationalTerritory.”,Journal“Globalizations”,Vol.10,No.1,25-46, http://dx.doi.org/10.1080/14747731.2013.760927, Columbia University, NY, USA

HOTL,ECVC,( European Coordination Via Campesina (ECVC), Hands-Off The Land (HOTL) Alliance),2013, "Land concentration, land grabbing andpeople's strugglesin Europe.

USAID COUNTRY PROFILE,2011,"PROPERTY RIGHTS AND RESOURCE GOVERNANCE ALBANIA-PROPERTY RIGHTS AND RESOURCE GOVERNANCE PROFILE”, http://usaidlandtenure.net/albania

FAO,2006," Land tenure Policy series", Rome, www.fao.org/3/a-a0464e.pdf

Braun.J,Dick.R,2009, "Land Grabbing" by Foreign Investors in DevelopingCountries: Risks and Opportunities.", IFPRI Policy Brief. 